\title{
Study on the Ecology of the Peregrine Falcon (Falco peregrinus Tunstall, 1771) in the Chusovaya River Nature Park
}

\author{
A. V. Khlopotova \\ Ural Federal University, ul. Mira 19, Yekaterinburg, 620002 Russia; \\ e-mail: alex.falco.pereginus@gmail.com \\ Received April 12, 2012
}

\begin{abstract}
Keywords: Peregrine Falcon, nesting biology, protected areas, Chusovaya River Nature Park, Sverdlovsk
\end{abstract} oblast

DOI: $10.1134 / \mathrm{S} 1067413613030065$

The Peregrine Falcon was a rare bird in Sverdlovsk oblast in the 1940s, and its abundance further decreased in the 1960s; in the 1970s, it was not recorded nesting in any of previously known localities, and since then occurred extremely rarely (Danilov, 1969; Danilov, Ryzhanovskii, and Ryabitsev, 1984). Records of the Peregrine Falcon in Sverdlovsk oblast are usually confined to rocky cliffs at the banks of rivers or other water bodies.

Most authors consider that the most important prerequisite for Peregrine Falcon nesting is the presence of rocky ledges, usually at river banks. In Sverdlovsk oblast, this landscape type is especially well represented in the valley of the Chusovaya River. In 2004, the Chusovaya River Nature Park was established there as a specially protected area of regional importance. One of the basic purposes of this institution is the development and implementation of effective conservation measures and the maintenance of ecological balance in the area exposed to recreational impact. The most scenic view in the park is that of rocky outcrops along the banks of the Chusovaya River. Some of them have the status of natural landmarks and serve as the main attraction for tourists visiting this area. These rocks are also a habitat of the Peregrine Falcon, and recreational activities directly threaten this species.

Monitoring of nesting Peregrine Falcons and studies on their ecology are performed by the author for rationalizing the recreational regime in nesting areas of the species. Such data can be used a basis for assigning the status of natural landmarks to nesting areas of the Peregrine Falcon and organizing new camping sites or transferring existing camping sites beyond these areas. Another important purpose is ecological education of tourists, members of expeditions, and local residents.

Classical methods for monitoring birds of prey have long been successfully used in Russia (Osmolovskaya, 1948; Galushin, 1971). The variant of the traditional method employed in this study is adapted to the spe- cific landscape of the Chusovaya River. It has been found that repeated patrolling on foot at the tops and bases of riverbank cliffs is much more effective than their survey from a boat on the river. The most likely time for a researcher to find nesting Peregrine Falcons begins around the middle of the nestling-feeding period (in the study region, the second 10 days of June to early July). The author hopes that her amendments to the main method for finding Peregrine Falcon nests will prove effective and can be recommended for future use.

In one nest, video recording was tested as a promising method to obtain comprehensive data on the nesting biology of this species. A video camera with an infrared light source (for night imaging) was installed in the nest using a mounting pod and connected to a LawMate PV digital video recorder and a rechargeable battery ( $12 \mathrm{~V}, 4.5 \mathrm{Ah})$. Thus, an approximately 30 -min episode of a female falcon feeding the nestlings was recorded, and its prey was identified as Turdus sp.

The total time of the battery life was only 8 hours. We optimized the technical parameters of the scheme and monitored two nests in 2012. It was possible to achieve continuous operation of the camera for 3 days without having to visit the nest. We ended up with a 694 and 288 hours of footage with 2 nests (Khlopotova and Shershnev, 2013).

To study the feeding of Peregrine Falcons, materials were collected at perches and feeding stations near the nests during every visit to the nesting cliff and from nests after they were left by nestlings. Feathers, food remains, and pellets were collected, and each sample was labeled.

Species identification of prey by bone remains makes it possible to determine the exact number of prey individuals found in the nest and around it. Analysis of bird pellets for estimating the composition of small mammal fauna in a particular area was first used by Pidoplichko (1925, 1937, 1963; cited from Shepel', 2008). The majority of researchers consider the results 


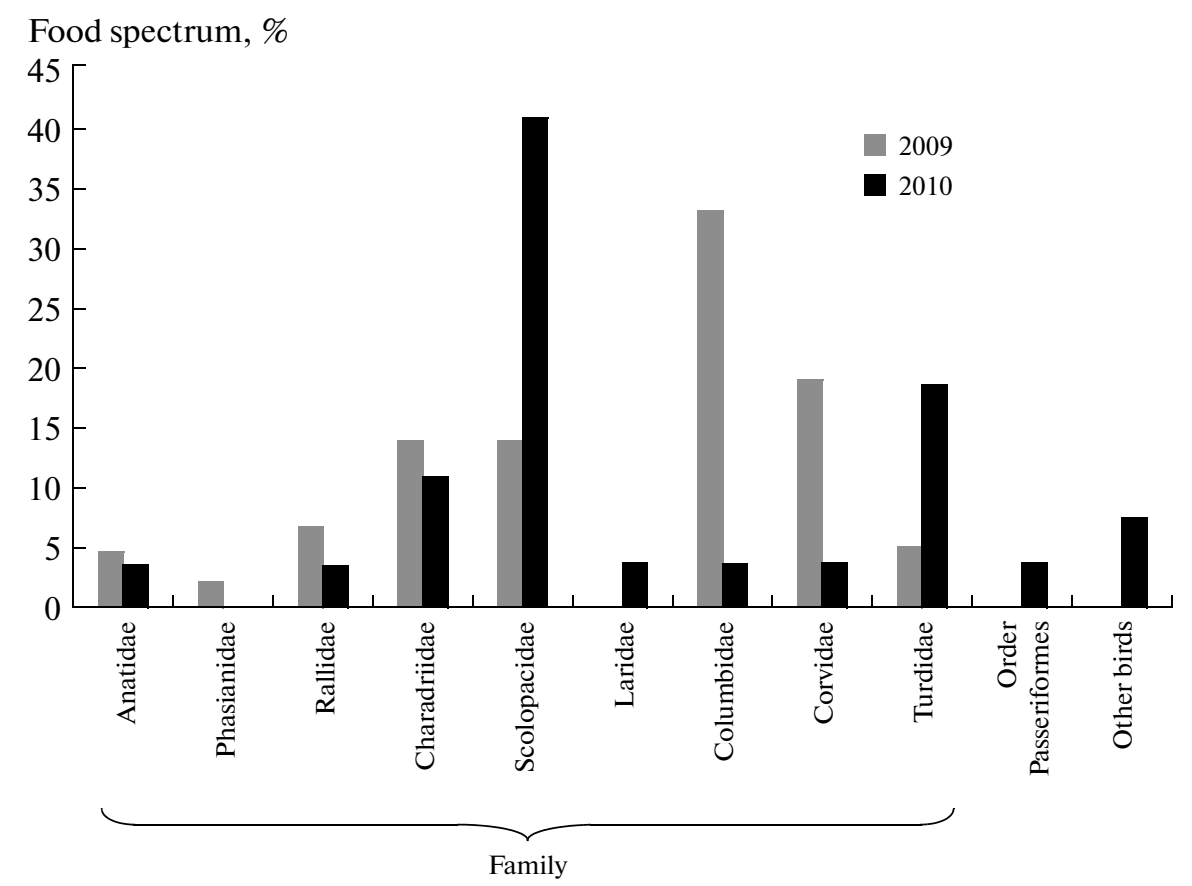

Food spectrum of the Peregrine Falcon on site 5 in 2009 and 2010: taxonomic groups of prey.

of pellet analysis to be sufficiently reliable for assessing the qualitative composition of the diet in birds of prey. In this study, prey species were identified by bone fragments from food remains and pellets with the aid of A.E. Nekrasov (Laboratory of Historical Zoology Laboratory, Institute of Plant and Animal Ecology, Ural Branch, Russian Academy of Sciences). Analysis of feathers collected from perches and nests made it possible to append the list of prey taxa. The feathers were identified referring to the collection of bird skins stored at the Subdepartment of Zoology of the Department of Biology, Institute of Natural Sciences of the Ural Federal University.

Nestlings aged 2-3 weeks were ringed with steel rings from by the Bird Ringing Center (Severtsov Institute of Ecology and Evolution, Russian Academy of Sciences, Moscow), which were attached with pliers to the tarsometatarsus.

Nesting places of Peregrine Falcons were reliably revealed in the Chusovaya River Nature Park in 2008 and 2009 (Larin, 2009; Khlopotova, 2009, 2010). The author has performed studies in this park since 2009 and revealed six nesting sites, coded by numbers $1-6$. Here, the nests located in sites 1, 5, and 6 are analyzed.

In these nests, nestlings hatched during the last 10 days of May, and fledglings left the nests between June 29 and July 10. Breeding success was 3, 1.7 and 2 fledglings per breeding pair in 2009, 2010 and 2012, respectively.

Feathers, food remains, and pellets were collected from Peregrine Falcon nests on site 5 in 2009 to 2012, from nests on sites 1 and 6 in 2010, from one nest on site 1 in 2011, and from nests on sites $1-6$ in 2012. A total of 544 bones were examined, and 171 individuals were taxonomically identified in the food spectra of the birds in 2009 and 2010. The material collected in 2011 and 2012 is currently being processed in the laboratory. A species or other taxon was classified as dominant in the food spectrum of the Peregrine Falcon if it accounted for the greatest proportion of all prey individuals identified in corresponding samples. Other food objects were regarded as secondary.

In 2009, the dominant food objects in the food spectrum of Peregrine Falcons on site 5 were members of the family Columbidae (33\%); in 2010, Scolopacidae $(41 \%)$ (figure). Secondary food objects included Corvidae in 2009 (19\%) and Turdidae in 2010 (19\%). A total of 43 individuals were identified by food spectrum analysis in 2009 samples, and 27 species were identified in 2010 samples. The left humerus was the bone most frequently found in the samples.

In the food spectrum of Peregrine Falcons on site 1 in 2010 , Turdidae were dominant $(22 \%)$, while Scolopacidae and Charadriidae were secondary taxa $(14 \%$ and $10 \%$, respectively). A total of 50 food objects were recorded in 2010. In particular, they included a vole of the genus Microtus (Cricetidae), whose skull was found in the nest, and a perch (Perca fluviatilis) represented by a single bone. In is unlikely, however, that Peregrine Falcons prey on fish. This perch bone probably appeared in the nest accidentally (e.g., from the stomach of some other bird), since no other perch remains have been found. 
In the food spectrum of Peregrine Falcons on site 6, shorebirds (Scolopacidae and Charadriidae) were dominant (31\%); secondary food objects included Turdidae and Laridae (18\% and 12\%, respectively).

Despite the broad food spectrum, the range of hunting techniques of the Peregrine Falcon is rather narrow. One of the fastest birds of prey, the Peregrine Falcon can catch up with any prey that has failed to hide underwater or amid vegetation. It is known from the literature that Peregrine Falcons almost always catch their prey in the air and only rarely from the ground. In reconstructions of the hunting methods and techniques of this species, it is necessary to take into account the types of biotopes around the nest. For instance, north of site 5 there is a floodplain meadow with small patches of trees, where ducks and shorebirds can nest. The dense vegetation along the boundary of the floodplain is apparently inhabited by Columbidae (Common Wood Pigeons). A colony of Fieldfares lives on top of the cliff on site 5 . In the field southeast of the cliff, Lapwings have been recorded. North of site 6 , there is another floodplain meadow with patches of fir-birch forest, which can be inhabited by Columbidae, Charadriidae, Scolopacidae, and Anatidae. In the environs of site 1, there are many clear-cut patches and glades without trees. Southeast and south of the nest on site 1, such open areas extend for about 15-20 $\mathrm{km}^{2}$. Birds such as the Eurasian Woodcock and European Nightjars may fall prey to the Peregrine Falcon while lekking at dusk. The presence of such birds in the food spectrum is additional evidence that the Peregrine Falcons hunt during the dark period. Moreover, owls are also present in their food spectrum. This concerns mainly the Short-Eared Owl, which lives in open landscapes and can hunt even after dawn, while the Long-Eared Owl is a mostly nocturnal bird of prey.

A distinctive feature of the nesting biology of the Peregrine Falcon is that the birds store the remains of prey and subsequently feed them to the nestlings. According to the researchers who described this behavior of Peregrine Falcons in the Western Caucasus (Veinberg, Komarov, and Lipkovich, 1986; Til'ba and Mnatsekanov, 2003), it allows the falcons to feed their nestlings regularly, regardless of the degree of prey activity. Such an explanation is quite probable. In general, food storage is characteristic mainly of nonmigrating species and is seldom observed in birds of prey.

Another distinctive feature recorded during the season of 2010 is that the falcons can also feed their nestlings at night, apparently with freshly caught prey. Two episodes of such unusual feeding were recorded and described during three nights of observations. The episode that took place at 3:39 a.m. (local time) on May 21, 2010 was described more comprehensively and supplemented by an audio recording of vocalization characteristic of the feeding process that was produced by the male, female, and nestlings.

\section{REFERENCES}

Danilov, N.N., Birds of the Middle and Northern Urals, Tr. Ural. Otd. Mosk. O-va Ispyt. Prir., Sverdlovsk, 1969, no. 3, pp. 119-122.

Danilov, N.N., Ryzhanovskii, V.N., and Ryabitsev, V.K., Ptitsy Yamala (Birds of the Yamal Peninsula), Moscow: Nauka, 1984.

Galushin, V.M., Abundance and territorial distribution of birds of prey in the central European part of the Soviet Union, Tr. Oksk. Gos. Zap., 1971, no. 8.

Khlopotova, A.V., Aspects of Peregrine Falcon nesting biology in the Reka Chusovaya Nature Park: An example of one pair, Okhrana, ekoprosveshchenie, rekreatsionnaya deyatel'nost', izuchenie bioraznoobraziya i kul'turnogo naslediya na OOPT: Materialy regional'noi nauch.-praktich. konf. (Investigation and Conservation of Biodiversity and Cultural Heritage, Ecological Education, and Recreation in Specially Protected Natural Areas: Proc. Region. Sci.Pract. Conf.), Nizhnii Tagil, 2009, pp. 147-150.

Khlopotova, A.V., Some aspects of Peregrine Falcon nesting biology in the Reka Chusovaya Nature Park, in Ekologiya ot yuzhnykh gor do severnykh morei (Ecology: From Southern Mountains to Northern Seas), Yekaterinburg, 2010, pp. 197-198.

Khlopotova, A.V. and Shershnev, M.Y., Video monitoring Peregrine Falcons in the nesting period in the Reka Chusovaya Nature Park, in Okhrana ptits $v$ Rossii: problemy i perspektivy (Conservation of birds in the Russia: Problems and Prospects), Moscow, 2013, pp. 127-128.

Larin, E.G., Some ornithological findings in the vicinities of the Reka Chusovaya Nature Park, in Materialy $k$ rasprostraneniyu ptits na Urale, v Priural'e i Zapadnoi Sibiri (Materials on the Distribution of Birds in the Cisural Region and Western Siberia), Yekaterinburg, 2009, pp. 110-111.

Osmolovskaya, V.I., The Ecology of Birds of Prey in the Yamal Peninsula, Tr. Inst. Geogr. Akad. Naik SSSR, Moscow, 1948, vol. 41, pp. 5-77.

Shepel', A.I., Possibilities of using material from droppings in studies on the diet of myophagous birds of prey, Materialy $V$ mezhdunar. konf. po khishchnym ptitsam Severnoi Evrazii (Proc. V Int. Conf. on Birds of Prey in Northern Eurasia), Ivanovo: Ivanov. Gos. Univ., 2008, pp. 21-24.

Til'ba, P.A. and Mnatsekanov, R.A., The Ecology of Peregrine Falcon (Falco peregrinus brookei) in the Western Caucasus, in 80 let Kavkazskomy zapovedniku: put' ot velikoknyazheskoi okhoty do vsemirnogo priridnogo naslediya (The 80th Anniversary of the Caucasian State Nature Reserve: From the Grand Duke's Hunting Estate to World Natural Heritage), Sochi: Prospekt, 2003, pp. 269-298.

Veinberg, P.I., Komarov, Yu.E., and Lipkovich, A.D., Rare birds of prey nesting in the North Ossetian State Nature Reserve, in Redkie i ischezayushchie vidy rastenii $i$ zhivotnykh, floristicheskie i faunisticheskie kompleksy Severnogo Kavkaza, nuzhdayushchiesya v okhrane (Rare and Endangered Plant and Animal Species and Floristic and Faunistic Complexes in the Northern Caucasus), Stavropol', 1986, pp. 92-93.

Translated by P. Petrov 